\title{
DESIGN AND IMPLEMENTATION OF A CO2 FLOOD UTILIZING ADVANCED RESERVOIR CHARACTERIZATION AND HORIZONTAL INJECTION WELLS IN A SHALLOW SHELF CARBONATE APPROACHING WATERFLOOD DEPLETION
}

$$
D O E / B C / 14991--10
$$

Cooperative Agreement Number:

Contractor Name and Address:

Date of Report:

Award Date:

Anticipated Completion Date:

Government Award for 1996 Fiscal Year:

Project Director:

DOE Project Officer:

Reporting Period:
DE-FC22-94BC14991

Phillips Petroleum Company 4001 Penbrook Street Odessa, Texas 79762

October 31, 1996

June 3, 1994

January 2, 2001

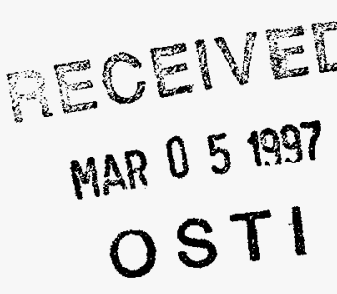

$\$ 2,659,515$

John S. Chimahusky

Jerry F. Casteel

July 1, 1996 - September 30, 1996

\section{NISTPETTON OF TMS DCCUMENT IS UNLIMITED 8}

\section{DISCLAIMER}

This report was prepared as an account of work sponsored by an agency of the United States Government. Neither the United States Government nor any agency thereof, nor any of their employees, makes any warranty, express or implied, or assumes any legal liability or responsibility for the accuracy, completeness, or usefulness of any information, apparatus, product, or process disclosed, or represents that its use would not infringe privately owned rights. Reference herein to any specific commercial product, process, or service by trade name, trademark, manufacturer, or otherwise does not necessarily constitute or imply its endorsement, recommendation, or favoring by the United States Government or any agency thereof. The views and opinions of authors expressed herein do not necessarily state or reflect those of the United States Government or any agency thereof. 


\section{DISCLAMMER}

Portions of this document may be illegible in electronic image products. Images are produced from the best available original document. 


\section{OBJECTIVE}

The first objective is to utilize reservoir characterization and advanced technologies to optimize the design of a carbon dioxide $\left(\mathrm{CO}_{2}\right)$ project for the South Cowden Unit (SCU) located in Ector County, Texas. The SCU is a mature, relatively small, shallow shelf carbonate unit nearing waterflood depletion. The second objective is to demonstrate the performance and economic viability of the project in the field. This report includes work on the reservoir characterization and project design objective and the demonstration project objective.

\section{SUMMARY OF TECHNICAL PROGRESS}

\section{BUDGET PHASE II}

\section{TASK V FIELD DEMONSTRATION}

\section{Drill, Re-Activate, and Convert Wells}

\section{Testing of reservoir characterization Well RC-3 (6-24)}

A step-rate test was run on reservoir characterization Well RC-3 during mid-July to determine the reservoir fracture pressure in the vicinity of the two horizontal injection wells. The results of this step-rate test were used to establish the maximum injection pressure for the horizontal injectors.

\section{Testing of Horizontal Injection Wells Nos. $6 \mathrm{C} 25 \mathrm{H}(\mathrm{H}-1)$ and $7 \mathrm{C} 11 \mathrm{H}(\mathrm{H}-2)$}

Prior to being placed on $\mathrm{CO}_{2}$ injection, injection profile surveys and falloff tests were conducted under water injection to verify that we had obtained an acceptable distribution of injection along the lateral section and to determine the mechanical condition and completion efficiency in the horizontal wells.

The injection profile work for the first horizontal well, Well No. $6 \mathrm{C} 25 \mathrm{H}$, was done by Cardinal Surveys Company. This consisted of a continuous flowmeter, quartz pressure sensor, temperature survys, capacitance and gamma ray probe conveyed on $1.25^{\prime \prime}$ coiled tubing. Good results were obtained even though the survey was done at relatively low injection rates under a very small pressure differential into the formation. The survey showed the injection water was entering the formation along most of the length of the lateral section. 
Injection pressure measurements and a pressure falloff test were run during the water injection period in Well No. 6C25H. High-quality falloff data were obtained. Initial pressures matched closely with the simulation model predictions along the horizontal traverse and permeability data derived from radial flow periods matched well with the history-matched permeabilities in the model. The length of the effective intervals taking fluid derived from model verification matching agreed with the injection profile survey results. The pressure falloff results indicated a good acid stimulation had been obtained from the coiled tubing acid wash completion in the horizontal section. Based on the favorable results in the injection profile and falloff data, the well was placed on $\mathrm{CO}_{2}$ injection during early July and slowly brought up to capacity injection at a bottomhole injection pressure slightly below the calculated formation parting pressure (from step-rate results on $\mathrm{RC}-3$ ). The injection rate stabilized very close to the expected rate forecast in the model.

The injection profile survey on the second horizontal well, Well No. $7 \mathrm{C} 11 \mathrm{H}$, was conducted by Halliburton using a different procedure. They opted to run a logging and injection program wherein coiled tubing and wireline were run in the injection well simultaneously with a Y-block and coiled tubing side-entry assembly attached to the coiled tubing below the spot valve. The tool consisted of positive and negative gamma-ray and temperature tool. A slug of more than one gallon of radioactive gel with 50 micron sand was used rather than the standard injection procedure of $1 \mathrm{cc}$ per station. A flowing temperature log and velocity shots were used to determine fluid entry. Results of the second injection profile survey were somewhat ambiguous and difficult to interpret. Halliburton's interpretation indicated injection fluid movement throughout all but the last 150 feet near the toe of the horizontal interval. In-house interpretation of the results, however, indicated that a good portion of the injected water could be entering the reservoir near the toe of the well.

A pressure falloff test was also run in Well No. $7 \mathrm{C} 11 \mathrm{H}$. This test did not show the same behavior as demonstrated in the first well. The test showed early linear flow behavior rather than early radial flow as in the first horizontal well. This second well was drilled approximately normal to the preferential parting direction indicated in earlier micro-frac tests conducted in two reservoir characterization wells. A step rate test was also conducted on the well, which showed a shift toward linear flow behavior and possible fracture extension above 2600 psi bottomhole injection pressure.

Low-volume injection of $\mathrm{CO}_{2}$ in the horizontal injection wells commenced in early July, following the pressure and injection profile testing. Higher-volume $\mathrm{CO}_{2}$ injection into Wells Nos. $6-25 \mathrm{H}$ and 7-11H commenced August 14, and August 29, 1996, respectively.

\section{Injection in Vertical Wag Injection Wells Nos. 2-26W and 2-27W}

Water injection commenced in vertical WAG injection Wells Nos. 2-26W and 2-27W in early July. Bottom-hole pressure surveys were run in both these vertical injection wells during early August, 
immediately prior to commencing $\mathrm{CO}_{2}$ injection. $\mathrm{CO}_{2}$ injection began July 19,1996 in Well No. 2-26W, at an initial wellhead pressure of 890 psig, and on July 22, 1996 in Well No. 2-27W.

\section{Drill multiple producing wells}

Two new producing wells were proposed for drilling during fourth quarter, Wells Nos. 7-13 and 715. Well No. 7-13 will be drilled as a replacement well for plugged and abandoned production Well No. 7-06. Well 7-15 will be drilled to improve the spacing in the northern portion of Section 18. This work was originally scheduled for 1997.

\section{Convert Five Wells for Water Injection}

Wells Nos. 5-02 and 8-18 were converted for use as water injection wells and are waiting on injection line tie-in.

\section{Reactivate Wells for Production}

Wells Nos. 7-02, 7-05 and 6-02 were reactivated for production.

\section{Construct, Modify, and Upgrade Facilities for Injection and Production}

\section{Purchase Land. Install Perimeter Fence and $\mathrm{H}_{2} \underline{\mathrm{S} \text { Monitors }}$}

All of the required private lots in Section 17 of the South Cowden Unit have been purchased. The sixth lot could not be purchased for a reasonable price; hence, the lot will not be purchased. Extra precautionary monitors and alarms will be installed along the lot line to protect the owner. This has been discussed and agreed with the Texas Railroad Commission (TRRC) to meet Rule 36 requirements.

The main 250-acre tract of land where $\mathrm{CO}_{2}$ flood facilities are located is currently being leased. Purchase of the land is anticipated in November.

Twenty of twenty-one hydrogen sulfide $\left(\mathrm{H}_{2} \mathrm{~S}\right)$ premised monitors have been installed and are operational. An additional $\mathrm{H}_{2} \mathrm{~S}$ monitor along the perimeter fence behind the private lot that could not be purchased will be added. If $\mathrm{H}_{2} \mathrm{~S}$ is detected by any of the monitors, an alarm is sent via radio to the Phillips Petroleum Odessa office South Cowden Unit (SCU) Supervisory Control and Data Acquisition (SCADA) computer, which in-turn sends a message to an operator on-call who will have an alpha-numeric pager. If the operator on-call cannot be reached, a list of people will be called until someone acknowledges the alarm. 
The perimeter fence is approximately $95 \%$ complete. This fence is being constructed to prevent public entrance into the project area, provide protection from exposure to $\mathrm{H}_{2} \mathrm{~S}$ and protect against vandalism. The fence will be completed now that all the private lots have been purchased.

\section{Construct Injection Facilities}

Installation of injection runs to all four of the $\mathrm{CO}_{2}$ WAG injection wells is completed. Installation to the water injection wells is complete for Wells Nos. 5-02 and 8-18. Tie-in of additional wells will be ongoing as wells are prepared for injection.

Installation is complete.

Construction and installation of the $\mathrm{H}_{2} \mathrm{O}$ and $\mathrm{CO}_{2}$ (WAG) manifold is completed. Since completion of the manifold with the $\mathrm{CO}_{2}$ /water meters, the meters have been modified to improve ${ }_{2} \mathrm{CO}$ measurement. The work is now complete.

Replacement of the old water injection system is essentially complete except for the lateral to injection well No. 5-02.

\section{Modify or Upgrade Production Facilities}

Construction of the new Tract 6 Satellite facility is approximately $90 \%$ complete. The Satellite facility will be ready within the next thirty (30) days. However, the Satellite facility will not be put into operation until the Unit experiences significant $\mathrm{CO}_{2}$ production.

\section{Construct Compression Facilities}

Production Operators, Inc. (POI) completed construction of their re-injection facility on June 21, 1996. The facility will continue to be idle until $\mathrm{CO}_{2}$ production increases enough to justify operating the compressors.

\section{Install Cathodic Protection}

No additional field work has been completed this quarter. Evaluation of the collected data from the well logs is ongoing and redesign of the system utilizing the new data continues. A decision to install the field wide cathodic protection will be made during fourth quarter 1996. 
Install Supervisory Control and Data Acquisition (SCADA) Equipment

The SCADA system has been installed and is operating. Installation of producing well pump-off controllers is $95 \%$ complete.

\section{Purchase $\mathrm{CO}_{2}$ and Operation of Recycle Compression}

The total volumes purchased for injection in all the wells for the quarter were:

$\begin{array}{lc} & \mathrm{MSCF} \mathrm{CO}_{2} \\ \text { July } & 10,446 \\ \text { August } & 90,687 \\ \text { September } & \underline{232,190} \\ \text { Total } & 333,323\end{array}$

The recycle compression facilities are currently not in use.

\section{TASK VI TECHNOLOGY TRANSFER}

During the last quarter, a paper entitled "Reservoir Characterization of an Upper Permain Platform Carbonate in Preparation for a Horizontal-Well CO${ }_{2}$ Flood, South Cowden Unit, West Texas," was written and submitted to the Oklahoma Geological Survey by Craig D. Caldwell. This paper was previously presented as a poster session at the March, 1996, meeting "Platform Carbonates of the Southern Midcontinent" sponsored by the OGS. The OGS is planning on publishing 1000 copies of the proceedings from this meeting.

An abstract for SPE Paper 37470, "The Evaluation of Two Different Methods of Obtaining Injection Profiles in $\mathrm{CO}_{2}$ WAG Horizontal Injection Wells," was submitted by Kimberly B. Dollens, James C. Shoumaker, Burl W. Wylie, and Phil Rice, for presentation at the 1997 SPE Production Operations Symposium, March 9-11, 1997, in Oklahoma City, Oklahoma. 